\title{
Does the high density of trichomes influence the parasitism of Liriomyza sativae by Opius scabriventris on melon cultivars?
}

\section{A alta densidade de tricomas influencia no parasitismo de Liriomyza sativae por Opius scabriventris em cultivares de meloeiro?}

\author{
Francisco Edivino Lopes Silva', Ewerton Marinho Costa², Elton Lucio Araújo ${ }^{1 *}$

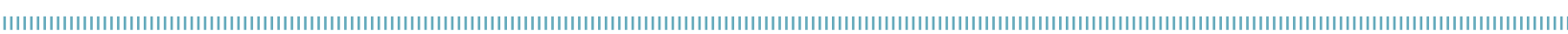

\begin{abstract}
Opius scabriventris (Hymenoptera: Braconidae) is considered an important parasitoid of the leafminer Liriomyza sativae (Diptera: Agromyzidae) in the main melon (Cucumis melo L.) producing areas in Brazil. However, there is no information on the influence of trichomes on melon plant leaves on the parasitoids' actions. Therefore, the aim of this investigation was to relate the influence of columnar trichome density on melon cultivars in the parasitism of $L$. sativae larvae by $O$. scabriventris. The study was conducted in laboratory conditions, in which melon cultivars were infested and the leafminer larvae were subjected to the parasitism. The results demonstrated that trichome density can influence the parasitism of $L$. sativae larvae by $O$. scabriventris. Among the studied materials, Piel de Sapo cultivar showed the highest density of trichomes in the leaves $\left(534\right.$ trichomes $/ \mathrm{cm}^{2}$ ) and the lowest parasitism (20\%).
\end{abstract}

KEYWORDS: Cucumis melo; biological control; parasitoid; integrated pest management.
RESUMO: Opius scabriventris (Hymenoptera: Braconidae) é considerado um importante parasitoide da mosca-minadora Liriomyza sativae (Diptera: Agromyzidae) nas principais áreas de produção de melão (Cucumis melo L.) do Brasil, no entanto, não há informações se a densidade de tricomas das folhas do meloeiro pode influenciar a ação desses parasitoides. Portanto, o objetivo deste trabalho foi relatar a influência da densidade de tricomas colunares de cultivares de meloeiro no parasitismo de L. sativae por O. scabriventris. O trabalho foi realizado em condiçóes de laboratório, em que os cultivares foram infestados e as larvas da mosca-minadora submetidas ao parasitismo. Os resultados demonstraram que a densidade dos tricomas pode influenciar no parasitismo de larvas de L. sativae por O. scabriventris. Entre os materiais estudados, o cultivar pele-de-sapo apresentou a maior densidade de tricomas nas folhas (534 tricomas $/ \mathrm{cm}^{2}$ ) e o menor parasitismo (20\%).

PALAVRAS-CHAVE: Cucumis melo; controle biológico; parasitoide; manejo integrado de pragas. 
The leafminer Liriomyza sativae Blanchard (Diptera: Agromyzidae) is an important pest in melon (Cucumis melo L.) crops, due to its larvae feeding on the foliar parenchyma, reducing the photosynthetic ability of the plant and, consequently, the total soluble solid level ( ${ }^{\circ}$ Brix) of its fruits (ARAUJO et al., 2013).

One of the main strategies for the integrated management of $L$. sativae in different crops is the use of biological control with parasitoids (LIU et al., 2009). Parasitoids of the Opius (Hymenoptera: Braconidae) genus are reported as an important biological control agents of Liriomyza, being among the species of natural enemies used for leafminer control in Europe and the United States (LIU et al., 2009; CORTEZ-MONDACA; VALENZUELA-ESCOBOZA, 2013). In the main melon-producing areas in Brazil, Opius scabriventris Nixon (Hymenoptera: Braconidae) is reported as a relevant natural enemy of Liriomyza (COSTA-LIMA et al., 2014; ARAUJO et al., 2015).

Despite the importance of parasitoids in regulating Liriomyza populations, little is known about the influence of the melon plant's morphological features on the parasitism. However, it is known that morphological leaf characteristics, such as trichomes density, can affect the parasitism (CARRILLO et al., 2008; KARIMZADEH et al., 2013; HUGAR et al., 2014). Trichomes are the epidermal appendages that give leaves a particular hairiness, and sometimes they become a mechanical barrier to parasitoid action (TIAN et al., 2012). These barriers make it difficult for parasitoids to access their host, mainly affecting the searching speed and, consequently, reducing the actions of these natural enemies (CARRILLO et al., 2008; WEI et al., 2013).

Therefore, the aim of this research was to relate the influence of columnar trichome density (SARRIA et al., 2010; PALOMARES-RIUS et al., 2016) on melon cultivars in the parasitism of $L$. sativae larvae by $O$. scabriventris, intending of contributing to the use of braconids in the integrated management of leafminer.

The study was carried out at the Applied Entomology Laboratory at the Universidade Federal Rural do Semi-Árido (UFERSA), in the state of Rio Grande do Norte, Brazil. Six cultivars of different melon types were used, belonging to the Inodorus (Yellow Iracema, Yellow Dry 9150, and Piel de Sapo Sancho) and Cantaloupensis (Cantaloupe Caribbean Dream,
Cantaloupe Florentino, and Galia Yelogal) groups. The insects used in the trials came from the maintenance rearing of the aforementioned laboratory.

The number of columnar trichomes in each cultivar was estimated by removing of 50 foliar disks $\left(1 \mathrm{~cm}^{2}\right)$, collected from the center of the leaves, sampling five plants from each cultivar. The plants used had two totally developed leaves ( \pm 15 days after planting). The trichome count was carried out using a stereoscopic microscope.

To evaluate the parasitism of $L$. sativae larvae by O. scabriventris, melon plants from each cultivar were grown in a greenhouse, and when two leaves had formed they were subjected to infestation by the leafminer for 30 minutes, in cages $(50 \times 50 \times 50 \mathrm{~cm})$ containing approximately 200 pairs of leafminer adults in each one. The plants were then transported back to the greenhouse, where they remained for 72 hours. After this period, the number of larvae per plant was counted. The plants were then placed in cages $(50 \times 50 \times 50 \mathrm{~cm})$ containing mated adult females of $O$. scabriventris, aged between 24 and 72 hours, one female for each 10 leafminer larvae, and they remained there for 24 hours. After this period of time, the leaves were removed from the plants and placed individually inside plastic trays, which were conditioned in a climate controlled room $\left(25 \pm 2{ }^{\circ} \mathrm{C}, 70 \pm 10 \%\right.$ relative humidity $\mathrm{RH}$ - and 12 photophase), where they remained until the formation of the puparia. The obtained puparia were counted and placed in Petri dishes closed with plastic film, in which they remained until the adults emergence (parasitoid or fly). The percentage of parasitism (PP) was calculated using the formula (Equation 1):

$\mathrm{PP}=[$ no. of emerged parasitoids $\div$ (no. of emerged parasitoids + no. of emerged leafminer $) \times 100]$

The experimental design used was completely randomized with 10 repetitions (plants) and six treatments (melon cultivars).

To statistically compare the parasitism, the averages were submitted to the non-parametric Kruskal-Wallis test using the level of significance of $5 \%$. Regression was also carried out correlating the percentage of parasitism with the number of trichomes for each melon cultivar. The analyses were carried out using the $\mathrm{R}$ Statistical Program (R DEVELOPMENT CORETEAM, 2011).

Table 1. Trichome density and parasitism in Liriomyza sativae larvae by Opius scabriventris on leaves of different melon cultivars.

\begin{tabular}{lcccc} 
Groups & Types & Cultivars & Trichome/cm ${ }^{2}$ & Parasitism* (\%) \\
Inodorus & Yellow & Iracema & 331 & $88.9 \mathrm{a}$ \\
\hline Inodorus & Yellow & Dry 9150 & 325 & $87.5 \mathrm{a}$ \\
\hline Inodorus & Piel de Sapo & Sancho & 534 & $20.0 \mathrm{~b}$ \\
\hline Cantaloupensis & Cantaloupe & Caribbean Dream & 197 & $73.3 \mathrm{a}$ \\
\hline Cantaloupensis & Cantaloupe & Florentino & 278 & $94.4 a$ \\
\hline Cantaloupensis & Galia & Yelogal & 182 & $80.0 \mathrm{a}$ \\
\hline
\end{tabular}

*Averages followed by the same letter in the column do not differ using the Kruskal-Wallis test ( $p>0.05)$. 
The trichome density observed varied from 182 to $534 / \mathrm{cm}^{2}$ with the lowest density being observed on Yelogal and the highest one on Sancho cultivar (Table 1). The percentage of parasitism on $L$. sativae larvae by $O$. scabriventris varied from 20 to $94 \%$, and Sancho cultivar was the only one that differed statistically from the rest, having the lowest parasitism (20\%) (Table 1).

Regarding the influence of trichome density in the parasitism, it was found that, in general, there was low correlation $\left(\mathrm{R}^{2}=0.5465\right)$, and these variables were inversely proportional. That is, the greater the number of trichomes on the leaves, the lower the parasitism (Fig. 1). However, the effect of trichome density over the parasitism was evident in Sancho cultivar, which had a high number of trichomes on the leaves, and reduced parasitism.

The negative influence of a high trichome density over parasitism was also observed by other researches. MULATU et al. (2006) verified that the higher trichome density in tomato plant (Solanum lycopersicum L.) leaves caused

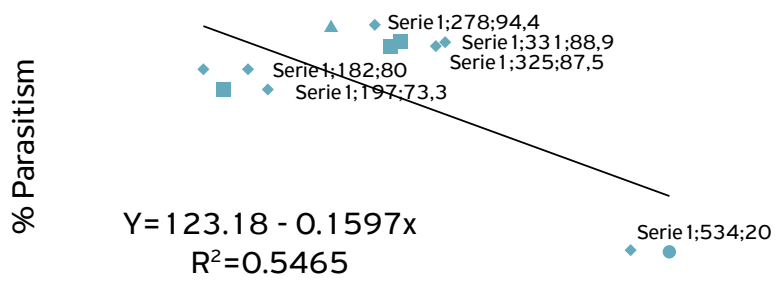

Number of trichomes $/ \mathrm{cm}^{2}$

Figure 1. Correlation between the number of trichomes $/ \mathrm{cm}^{2}$ and parasitism of Liriomyza sativae larvae by Opius scabriventris, on different melon cultivars. reduction of the parasitism of Diadegma pulchripes Kokujev (Hymenoptera: Ichneumonidae) in Phthorimaea operculella Zeller (Lepidoptera: Gelechiidae). According to CARRILLO et al. (2008), often a high trichome density causes increase in parasitoid search time for a host, reducing its efficiency. Specifically regarding parasitoids of leafminer, WEI et al. (2013) observed that tomato plant crops with high trichome densities presented lower parasitism of Opius dissitus (Muesebeck) (Hymenoptera: Braconidae) in Liriomyza huidobrensis (Blanchard) (Diptera: Agromyzidae).

However, despite advances in the research field, studies focusing on estimating the influence of trichome density over braconid parasitism in leafminer larvae on melon cultivars are rare. Thus, the results obtained here demonstrate that trichome density on the leaves of some melon cultivars can interfere in the parasitism of $L$. sativae larvae by O. scabriventris. Therefore, this aspect of trichome density should be considered in cases there is interest in using the $O$. scabriventris parasitoids for integrated management of leafminer in melon crops.

\section{ACKNOWLEDGEMENTS}

To the Brazilian National Council for Scientific and Technological Development (Conselho Nacional de Desenvolvimento Cientifico e Tecnológico - CNPq), for the scientific initiation and research productivity scholarships granted to the authors Francisco E. L. Silva and Elton L. Araujo, respectively.

\section{REFERENCES}

ARAUJO, E.L.; NOGUEIRA, C.H.F.; MENEZES NETTO, A.C.; BEZERRA, C.E.S. Biological aspects of the leafminer Liriomyza sativae (Diptera: Agromyzidae) on melon (Cucumis melo L.). Ciência Rural, v.43, n.4, p.579-582, 2013. http://dx.doi.org/10.1590/ so $103-84782013000400003$

ARAUJO, E.L.; NOGUEIRA, C.H.F.; BEZERRA, C.E.; COSTA, E.M. Toxicity of insecticides used in melon crops to Opius scabriventris (Hymenoptera: Braconidae). Bioscience Journal, v.31, n.5, p.1370-1377, 2015. http://dx.doi.org/10.14393/BJ-v3 1 n5a2015-26408

CARRILLO, D.; PEÑA, J.E.; CAPINERA, L.J. Effect of host plants on successful parasitism by Haeckeliania sperata (Hymenoptera: Trichogrammatidae) on Diaprepes abbreviatus (Coleoptera: Curculionidae) eggs. Environmental Entomology, v.37, n.6, p.1565-1572,2008.

CORTEZ-MONDACA, E.; VALENZUELA-ESCOBOZA, F.A. Natural enemies of the leafminerLiriomyza trifolii (Diptera:
Agromyzidae): challenges and perspectives for its biological control. Southwestern Entomologist, v.38, n.4, p.643-660,2013. https://doi.org/10.3958/059.038.0410

COSTA-LIMA, T.C.; CHAGAS, M.C.M.; PARRA, J.R.P. Temperature-dependent development of two Neotropical parasitoids of Liriomyza sativae (Diptera: Agromyzidae). Journal of Insect Science, v.14, n.245, 2014. http://dx.doi.org/10.1093/ jisesa/ieu 107

HUGAR, S.V.; SHARMA, H.C.; BASAVAN GOUD, K. Pigeonpea genotypes influence parasitization preference, survival and development of the Helicoverpa armigera larval parasitoid, Campoletis chlorideae. SpringerPlus, v.3, p.1-8, 2014. http:// dx.doi.org/10.1186/2193-1801-3-378

KARIMZADEH, J.; HARDIE, J.; WRIGHT, D.J. Plant resistance affects the olfactory response and parasitism success of Cotesia vestalis. Journal of Insect Behavior, v.26, p.35-50, 2013. 
LIU, T.X.; KANG, L.; HEINZ, K.M.; TRUMBLE, J. Biological control of Liriomyza leafminers: progress and perspective. Perspectives in Agriculture, Veterinary Science, Nutrition and Natural Resources, v.4, n.4, p.1-16, 2009. http://dx.doi.org/10.1079/ PAVSNNR20094004

MULATU, B.; APPLEBAUM, S.W.; COLL, M. Effect of tomato leaf traits on the potato tuber moth and its predominant larval parasitoid: A mechanism for enemy-free space. Biological Control, v.37, p.231-236, 2006

PALOMARES-RIUS, F.J.; YUSTE-LISBONA, F.J.; VIRUEL, M.A.; LÓPEZ-SESÉ, A.I.; GÓMEZ-GULLAMÓN, M.L. Inheritance and QTL mapping of glandular trichomes type I density in Cucumis melo L. Molecular Breeding, v.36, n.9, p.132, 2016.

R DEVELOPMENT CORE TEAM. 2011. R: A language and environment for statistical computing. R Foundation for Statistical
Computing, Vienna, Austria. ISBN 3-900051-07-0. Available from: <http://www.r-project.org/>. Accessed on: May 202016.

SARRIA, E.; PALOMARES-RIUS, F.J.; LÓPEZ-SESÉ, A.I.; HEREDIA, A.; GÓMEZ-GULLAMÓN, M.L. Role of leaf glandular trichomes of melon plants in deterrence of Aphis gossypii Glover. Plant Biology, v. 12, n.3, p.503-511, 2010 .

TIAN, D.; TOOKER, J.; PEIFFER, M.; CHUNG, S.H.; FELTON, G.W. Role of trichomes in defense against herbivores: comparison of herbivore response to woolly and hairless trichome mutants in tomato (Solanum lycopersicum). Planta, v.236, p.1053-1066, 2012.

WEI, J.; YAN, L.; REN, Q.; LI, C.; GE, F.; KANG, L. Antagonism between herbivore-induced plant volatiles and trichomes affects tritrophic interactions. Plant, Cell and Environment, v.36, p.315-327, 2013. 